\title{
IDENTIFIKASI KESALAHAN-KESALAHAN SISWA DALAM MENYELESAIKAN SOAL CERITA PADA MATERI SISTEM PERSAMAAN LINEAR DUA VARIABEL BERDASARKAN PROSEDUR NEWMAN
}

\author{
Ayu Habibah*, Nandang, Sudirman \\ Universitas Wiralodra \\ *ayuhabibah402@gmail.com
}

Dikirim: 7 Oktober 2019. Diterima: 22 Januari 2020. Dipublikasikan: 31 Januari 2020

\begin{abstract}
ABSTRAK
Penelitian ini bertujuan untuk mengetahui kesalahan-kesalahan siswa dalam menyelesaikan soal cerita pada materi Sistem Persamaan Linear Dua Variabel berdasarkan prosedur Newman dan faktor-faktor penyebab siswa melakukan kesalahan tersebut. Jenis penelitian yang digunakan adalah penelitian kualitatif. Subjek dalam penelitian ini adalah siswa kelas X SMKN Balongan sebanyak 3 orang, yang melakukan kesalahan dalam menyelesaikan soal cerita pada materi Sistem Persamaan Linier Dua Variabel. Berdasarkan hasil penelitian ditemukan bahwa kesalahan yang banyak dilakukan ialah pada tahap keterampilan proses dan penulisan jawaban akhir. Adapun faktor-faktor yang menyebabkan kesalahan siswa dalam menyelesaikan soal cerita tersebut karena tidak terbiasa menyelesaikan soal dengan menggunakan prosedur Newman. Siswa kurang memahami dalam mengubah makna kata ke dalam model matematika. Siswa kurang latihan mengerjakan soal cerita.
\end{abstract}

Kata kunci:Kesalahan Siswa, Soal Cerita, Prosedur Newman.

\begin{abstract}
This study aims to determine students' errors in completing the story test on the Linear Equation System Two Variables Material based on the Newman procedure and the factors that cause the students in making these errors. The type of research used is qualitative research. The subjects in this study were 3 students in grade $\mathrm{X}$ of SMKN Balongan, who made errors in completing the story test on the Linear Equation System Two Variables Material. Based on the results of the study it was found that the most errors made were at the stage of process skills and writing the final answers. The factors that cause students in making the error in completing the story test because they are not accustomed in completing the test by using the Newman procedure. Students are lack of understanding in changing the meaning of words into mathematical models. Students are lack of practice in doing the story test.
\end{abstract}

Keywords: Students' errors, Story Test, Newman Procedures.

\section{Pendahuluan}

Matematika merupakan suatu ilmu yang berkaitan dengan hal yang abstrak, berkenaan dengan representasi simbol, dan aturan dalam konteks berpikir manusia. Menurut Rahayuningsih \& Kohar (2014: 109) bahwa matematika adalah ilmu yang berkenaan dengan konsep abstrak. Hal ini sejalan dengan pendapat Farida (2015: 42) bahwa matematika berkenaan dengan konsep representasi simbol, dan aturan dalam konteks berpikir manusia. Matematika memberikan banyak manfaat bagi kehidupan, menurut Herman Hudojo (dalam Mulyadi, dkk, 2015: 317) bahwa matematika merupakan suatu alat untuk mengembangkan cara berpikir.

Menurut Farida (2015: 43) bahwa pembelajaran matematika merupakan proses interaksi dan komunikasi antara guru dengan siswa dalam menyampaikan materi matematika, oleh karena itu, tujuan pembelajaran matematika ialah siswa mampu memahami suatu konsep matematika dan mampu menggunakan kemampuannya untuk menyelesaikan masalah matematika. Terkait dengan masalah matematika, masih banyak peserta didik yang mengalami kesulitan dalam menyelesaikan soal cerita matematika (Rahmania \& Rahmawati, 2017: 166). Soal cerita merupakan modifikasi soal-soal hitungan 


\section{Range: Jurnal Pendidikan Matematika Vol.1 No.2 Tahun 2020 Ayu Habibah, dkk.}

yang mempunyai peranan penting untuk mengimplementasikan pembelajaran dalam kehidupan seharihari (Nurussafa'at, dkk, 2016: 175). Dalam menyelesaikan soal cerita matematika, siswa harus dapat memahami terlebih dahulu isi soal cerita tersebut, kemudian siswa menarik kesimpulan permasalahan yang harus diselesaikan dan memisalkannya dengan simbol-simbol matematika, sampai pada tahap akhir yaitu penyelesaian (Rindyana, dkk, 2013). Seringkali dijumpai pada soal cerita yang membutuhkan kemampuan pemahaman dan keterampilan yang sangat menyeluruh dan mumpuni, menyadari akan pentingnya soal cerita dalam kehidupan sehari-hari, siswa perlu menguasainya dengan baik dan benar, namun dalam kenyataannya, keterampilan berpikir dan menyelesaikan soal cerita matematika masih rendah (Kholishoh, dkk, 2017: 17).

Materi Sistem Persamaan Linear Dua Variabel (SPDLV) merupakan salah satu materi pada pelajaran matematika yang banyak menampilkan soal cerita dengan harapan siswa sapat menyelesaikan dengan benar. Rahayuningsih \& Kohar (2014) dalam penelitiannya mengatakan bahwa masih banyak siswa yang kesulitan mempelajari materi SPLDV, dimana siswa belum mampu menyusun pemisalan kalimat bahasa sehari-hari ke dalam persamaan matematika.

Penelitian ini dilaksanakan di salah satu sekolah menengah kejuruan di Indramayu, yaitu SMKN Balongan beralamat di Jalan Raya Sukaurip No. 35 Kecamatan Balongan, Kabupaten Indramayu. Keadaan lingkungan sekolah yang terlihat asri lengkap dengan berbagai tanaman, bersih, dan lengkap dengan ruang-ruang laboraturium komputer, laboraturium listrik, serta sarana dan prasarananya lainnya.

Selanjutnya berdasarkan hasil observasi dan wawancara dengan salah satu guru matematika SMKN Balongan menyatakan bahwa masih banyak siswa yang melakukan kesalahan dalam menyelesaikan soal cerita pada materi Sistem Persamaan Linear Dua Variabel dikarenakan merasa kesulitan, masih bingung dan salah dalam melakukan perhitungan operasional serta belum memahami konsep dengan sepenuhnya dalam menyelesaikan soal cerita matematika.

Untuk mengetahui kesalahan-kesalahan siswa, maka perlu identifikasi kesalahan siswa, agar mendapatkan gambaran yang jelas dan rinci atas kelemahan-kelemahan siswa dalam menyelesaikan soal cerita. Salah satu cara yang dapat digunakan untuk menganalisis kesalahan jawaban siswa yaitu dengan menggunakan prosedur Newman (Son, Darhim \& Fatimah, 2019: 2). Dalam hal ini jika siswa ingin menyelesaikan suatu soal matematika bentuk cerita maka harus melalui lima langkah sitematis, yaitu: (1) membaca soal (reading), yaitu ketika siswa membaca soal, maka direpresentasikan sesuai dengan pemahamannya; (2) memahami masalah (comprehension), yaitu siswa mengerti masalah dengan menyebutkan bagian yang diketahui dan ditanyakan dalam soal; (3) transformasi (transformation), yaitu siswa dapat mentransformasikan masalah dengan menentukan metode akan digunakan dalam menyelesaikan soal; (4) keterampilan proses (process skill), yaitu siswa melakukan proses perhitungan berdasarkan aturan matematika yang telah direncanakan; (5) penulisan jawaban akhir (encoding), yaitu siswa menuliskan jawaban akhir dari penyelesaian soal (Son, et al., 2019: 2, Oktaviana, 2017: 23, Miherda dkk, 2014: 4-5).

Berdasarkan uraian di atas, maka tujuan penelitian ini adalah: 1). Untuk mengetahui kesalahankesalahan siswa dalam menyelesaikan soal cerita pada materi Sistem Persamaan Linear Dua Variabel berdasarkan prosedur Newman. 2) Untuk mengetahui penyebab terjadinya kesalahan yang dilakukan siswa dalam menyelesaikan soal cerita pada materi Sistem Persamaan Linear Dua Variabel berdasarkan prosedur Newman.

\section{MetodePenelitian}

Pendekatan penelitian yang digunakan dalam penelitian ini merupakan pendekatan kualitatif. Menurut Moleong (2011: 6) bahwa penelitian kualitatif adalah penelitian yang bermaksud untuk memahami fenomena yang dialami subjek penelitian dengan cara deskripsi dalam bentuk kata-kata dan bahasa, pada suatu konteks khusus yang alamiah dan dengan memanfaatkan berbagai metode alamiah.

Peneliti memilih menggunakan metode penelitian kualitatif untuk menentukan cara mencari, mengumpulkan, mengolah dan menganalisis data hasil penelitian tersebut. Penelitian kualitatif ini dapat 


\section{Range: Jurnal Pendidikan Matematika Vol.1 No.2 Tahun 2020 Ayu Habibah, dkk.}

digunakan untuk memahami karakteristik subjek penelitian yakni siswa yang membuat kesalahan dalam mempelajari materi Sistem Persamaan Linear Dua Variabel.

Penelitian ini bertempat di SMKN Balongan yang beralamatkan di Jalan Raya Sukaurip No. 35, Kecamatan Balongan, Kabupaten Indramayu. Subjek dalam penelitian ini adalah siswa kelas X SMKN Balongan sejumlah 3 orang, yang melakukan kesalahan dalam menyelesaikan soal cerita pada materi Sistem Persamaan Linier Dua Variabel (SPLDV).

Sehubungandengansubyekpenelitian, peneliti memutuskan informan pertama yang paling sesuai ialah Wakil Kepala Sekolah bagian kurikulum SMKN Balongan, informan kedua yaitu Guru Mata Pelajaran Matematika, dan 3 siswa yang melakukan kesalahan dalam menyelesaikan soal cerita pada materi Sistem Persamaan Linier Dua Variabel.

Pada penelitian ini, teknik pengumpulan data dilakukan dengan cara observasi, dokumentasi, wawancara, dan catatan lapangan. Observasi dilakukan dengan mengamati dan mencatat langsung data dari objek penelitian. Mengamati kegiatan belajar siswa kelas X di sekolah, yaitu untuk mengamati siswa saat menyelesaikan soal cerita materi Sistem Persamaan Linier Dua Variabel. Selanjutnya wawancara mendalam untuk memperoleh data yang akurat terkait kesalahan-kesalahan siswa dalam menyelesaikan soal cerita materi Sistem Persamaan Linear Dua Variabel. Alat bantu yang digunakan dalam proses wawancara adalah telepon selular, digital camera, dan buku catatan. Sumber dokumentasi pada penelitian ini terdiri dari dokumen dan rekaman berupa foto, video, rekaman serta data-data mengenai kesalahankesalahan siswa dalam menyelesaikan soal cerita materi tersebut. Catatan lapangan dalam penelitian ini berkaitan dengan wawancara dan pengamatan terhadap kesalahan-kesalahan siswa dalam menyelesaikan soal cerita materi di atas.

Dalam penelitian ini analisis data diambil berdasarkan model Miles dan Huberman (dalam Sugiyono, 2017: 246). Aktivitas dalam analisis data, yaitu: reduksi data (data reduction), penyajian data (data display), dan penarikan kesimpulan (conclusion drawing/verification).

Kemudian melakukan triangulasi sebagai pengecekan data dengan menggabungkan dari berbagai teknik pengumpulan dan sumber data. Dalam hal ini yaitu triangulasi sumber untuk menguji kredibilitas data dengan cara mengecek data yang telah diperoleh melalui beberapa sumber. Triangulasi waktu yaitu dalam rangka pengujian kredibilitas data dengan melakukan pengecekan berupa dengan wawancara dan observasi pada waktu yang berbeda. Triangulasi teknik yaitu untuk menguji kredibilitas data dilakukan dengan cara mengecek data kepada sumber yang sama dengan teknik yang berbeda. Bila dengan tiga teknik pengujian kredibilitas data tersebut, menghasilkan data yang berbeda-beda maka peneliti melakukan diskusi lebih lanjut kepada sumber data yang bersangkutan atau yang lain, untuk memastikan data mana yang dianggap benar.

\section{HasilPenelitiandanPembahasan}

Berdasarkan hasil analisis, maka diambil subjek penelitian dengan cara membuat peringkat berdsasarkan nilai yang diperoleh siswa, kemudian dibagi menjadi tiga kelompok, yaitu kelompok tinggi, sedang, dan rendah. Pengambilan subjek dilakukan secara acaksatu orang mewakili masing-masing kelompok, yakni kelompok tinggi diambil subjek penelitian $1\left(\mathrm{~S}_{1}\right)$, kelompok sedang diambil subjek penelitian $2\left(\mathrm{~S}_{2}\right)$, dan kelompok rendah diambil subjek penelitian $3\left(\mathrm{~S}_{3}\right)$. Setiap subjek penelitian dianalisis hasil pekerjaan tes, kemudian diberikan penguatan melalui triangulasi berdasarkan hasil observasi dan hasil wawancara.Namadanbesarnyaskorsiswa, disajikandalamTabel 1 berikut.

Tabel 1. Tabel Subjek Penelitian

\begin{tabular}{ccc}
\hline No. & NamaSiswa & SkorTes \\
\hline 1 & $\mathrm{~A}_{12}$ & 23 \\
2 & $\mathrm{~A}_{01}$ & 16 \\
3 & $\mathrm{~A}_{25}$ & 13 \\
\hline
\end{tabular}




\section{Range: Jurnal Pendidikan Matematika Vol.1 No.2 Tahun 2020 Ayu Habibah, dkk.}

Subjekpenelitian 1 (S1) dari 3 soal yang dikerjakan, soal yang terdapatkesalahandalampengerjaanadalahsoalnomor 1 .Petikansoalnomor 1 adalahUmurSani 7 tahunlebihtuadariumur Ari. Sedangkanjumlahumurmerekaadalah 43 tahun. BerapakahumurSanidan Ari?Hasilpekerjaan $S_{1}$ sepertipadagambar 1 berikut.

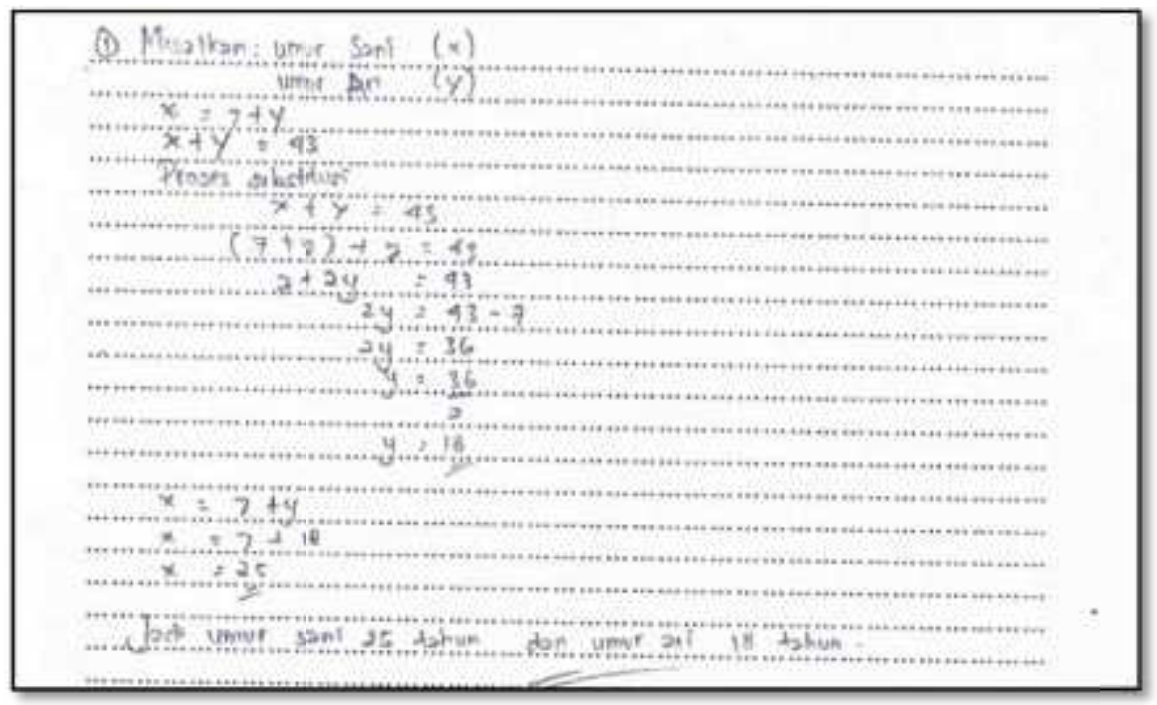

Gambar 1. Gambar 1. Jawaban $S_{1}$ terhadap soal nomor 1

Berdasarkan hasil pada lembar penyelesaian dan wawancara, dapat diambil kesimpulan bahwa S1 mengalami kesalahan pada tahap membaca dan memahami soal dengan tidak menuliskan apa yang diketahui dan ditanyakan pada soal, selanjutnya pada tahap transformation, S1 sudah benar dalam membuat pemisalan matematika. Kemudian pada tahap keterampilan proses, S1 sudah benar dalam melakukan perhitungan, dan pada tahap penulisan jawaban akhir, S1 sudah benar menuliskan akhir jawaban sesuai permasalahan soal. Pada saat proses wawancara berlangsung, S1 mampu membaca dan memahami permasalahan soal.

Subjek penelitian 2 (S2) dari 3 soal yang dikerjakan, soal yang terdapat kesalahan dalam pengerjaan adalah soal nomor 2 dan nomor 3.Petikansoalnomor 2 adalah "Padapertunjukanseniterjual 500 lembarkarcis yang HargakarciskelasEkonomiadalahRp terdiridarikarciskelasEkonomidankarciskelasUtama.

\section{JikahasilpenjualanseluruhkarcisadalahRp $3.360 .000,00$}

terjual?" Hasilpekerjaan $\mathrm{S}_{2}$ sepertipadagambar 2 berikut.

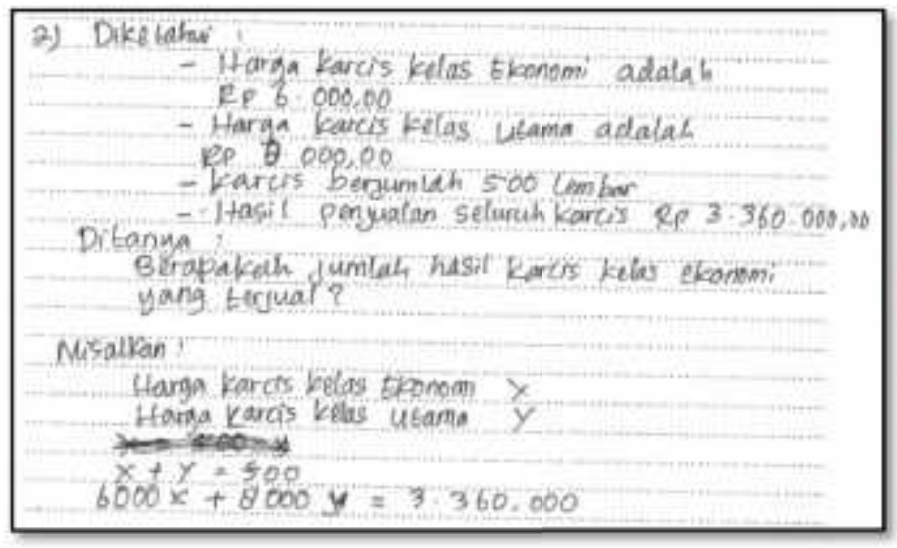
dankelasUtamaadalahRp

$8.000,00$ BerapakahjumlahkarciskelasEkonomi yang

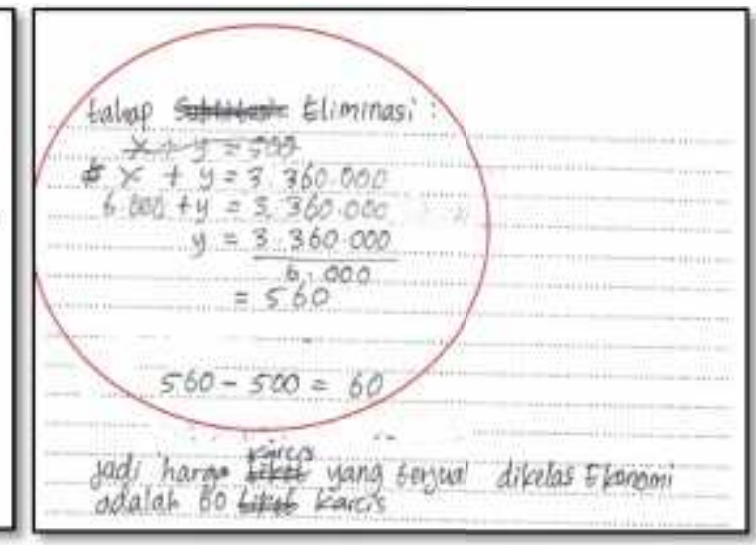

Gambar 2. Jawaban $S_{2}$ terhadap soal nomor 2 


\section{Range: Jurnal Pendidikan Matematika Vol.1 No.2 Tahun 2020 Ayu Habibah, dkk.}

Berdasarkan hasil pada lembar penyelesaian dan wawancara, bahwa $S_{2}$ pada tahap transformation, diketahui bahwa subjek sudah benar dalam membuat pemisalan dengan variabel x dan $\mathrm{y}$, akan tetapi subjek mengalami kesalahan dalam melakukan proses keterampilan proses, subjek salah dalam menggunakan aturan metode eliminasi, akibatnya subjek salah dalam menjawab pemasalahan dalam soal, sehingga menuliskan jawaban akhir yang tidak tepat. Pada saat proses wawancara berlangsung, $\mathrm{S}_{2}$ mampu membaca dan memahami permasalahan soal, kemudian pada tahap keterampilan proses, $\mathrm{S}_{2}$ salah dalam melakukan aturan penyelesaian metode yang digunakan.

Petikansoalnomor 3 adalah "Intan, Sofidan Hani membelibukudanpulpenbersama-sama di sebuahtoko. Intanmembeli 2 buahbukudan 7 batangpulpensehargaRp 14.000,00. SedangkanSofimembeli 4 buahbukudan 4 batangpulpensehargaRp 12.500,00. Berapa yang akandibayar Hani jikamembeli2 lusinbukudan 1 lusinpulpen?" Hasilpekerjaan $\mathrm{S}_{2}$ sepertipadagambar 3 berikut.

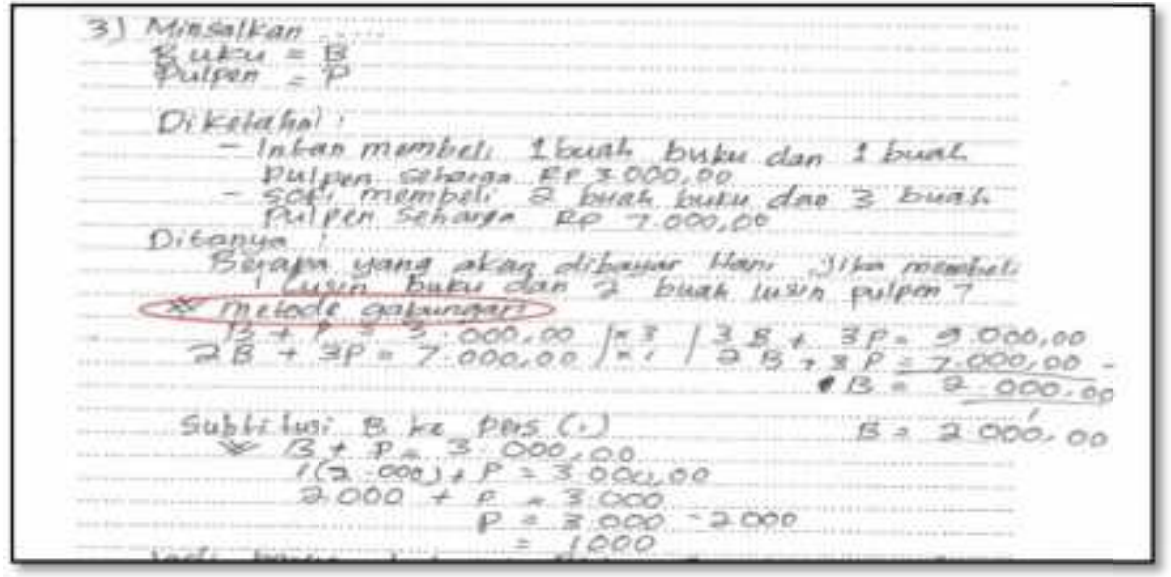

Gambar 3. Jawaban $\mathrm{S}_{2}$ terhadap soal nomor 3

Berdasarkan hasil pada lembar penyelesaian dan wawancara, bahwa S2 mengalami kesalahan pada tahap keterampilan proses. S2 sudah benar menuliskan pemisalan matematika untuk buku dan pulpen, akan tetapi langsung menuliskan pemisalan selanjutnya pada tahap keterampilan proses. Kemudian pada tahap keterampilan proses, S2 tidak menuliskan lengkap nama metode penyelesaian yang digunakan, yang seharusnya metode gabungan eliminasi substitusi. Pada saat proses wawancara berlangsung, S2 mampu membaca dan memahami permasalahan soal, serta dapat menyelesaikan soal dengan menggunakan metode yang benar.

Subjek penelitian $3\left(\mathrm{~S}_{3)}\right.$ dari 3 soal yang dikerjakan, soal yang terdapat kesalahan dalam pengerjaan adalah soal nomor 1, 2 dan 3.Soalnomor 1, 2, dan 3 samasepertipetikansebelumnya. Hasilpekerjaan $\mathrm{S}_{3}$ terhadapsoalnomor 1 sepertipadagambar 4 berikut.

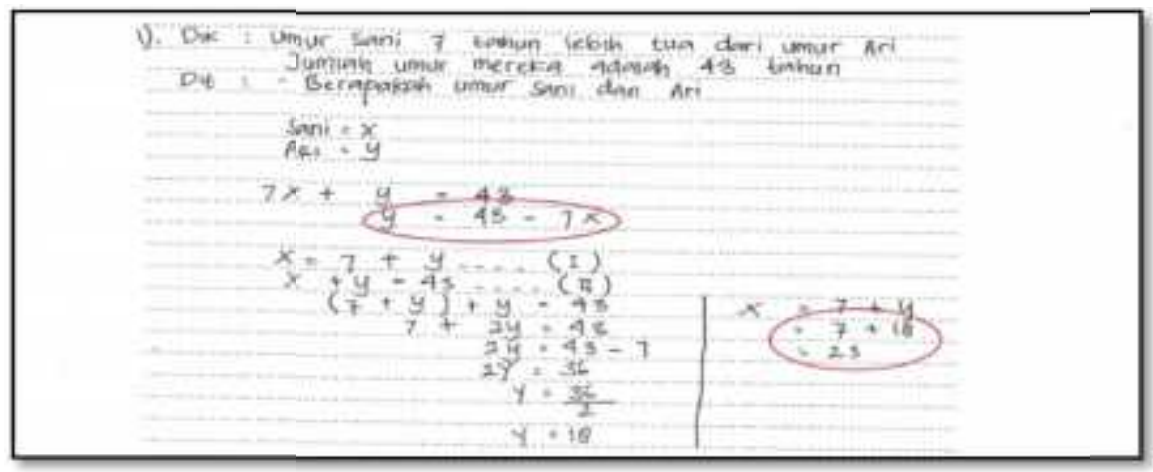

Gambar 4. Jawaban $S_{3}$ terhadap soal nomor 1 


\section{Range: Jurnal Pendidikan Matematika Vol.1 No.2 Tahun 2020 Ayu Habibah, dkk.}

Berdasarkan hasil pada lembar penyelesaian dan wawancara, bahwa $S_{3}$ mengalami kesalahan pada tahap transformasi masalah. $S_{3}$ sudah benar dalam membuat pemisalan matematikanya, akan tetapi menuliskan pemisalan yang tidak perlu dan tidak dapat menjelaskan pemisalan yang dipakai, hal ini dikarenakan $\mathrm{S}_{3}$ belum memahami akan permasalahan soal, serta belum paham dalam merubah kalimat ke dalam model matematis. Pada tahap keterampilan proses, $S_{3}$ salah dalam melakukan operasi penjumlahan, sehingga memperoleh jawaban yang tidak tepat. Kemudian pada tahap penulisan jawaban akhir, $\mathrm{S}_{3}$ tidak menuliskan jawaban akhir.

Hasilpekerjaan $\mathrm{S}_{3}$ terhadapsoalnomor 2 sepertipadagambar 5 berikut.

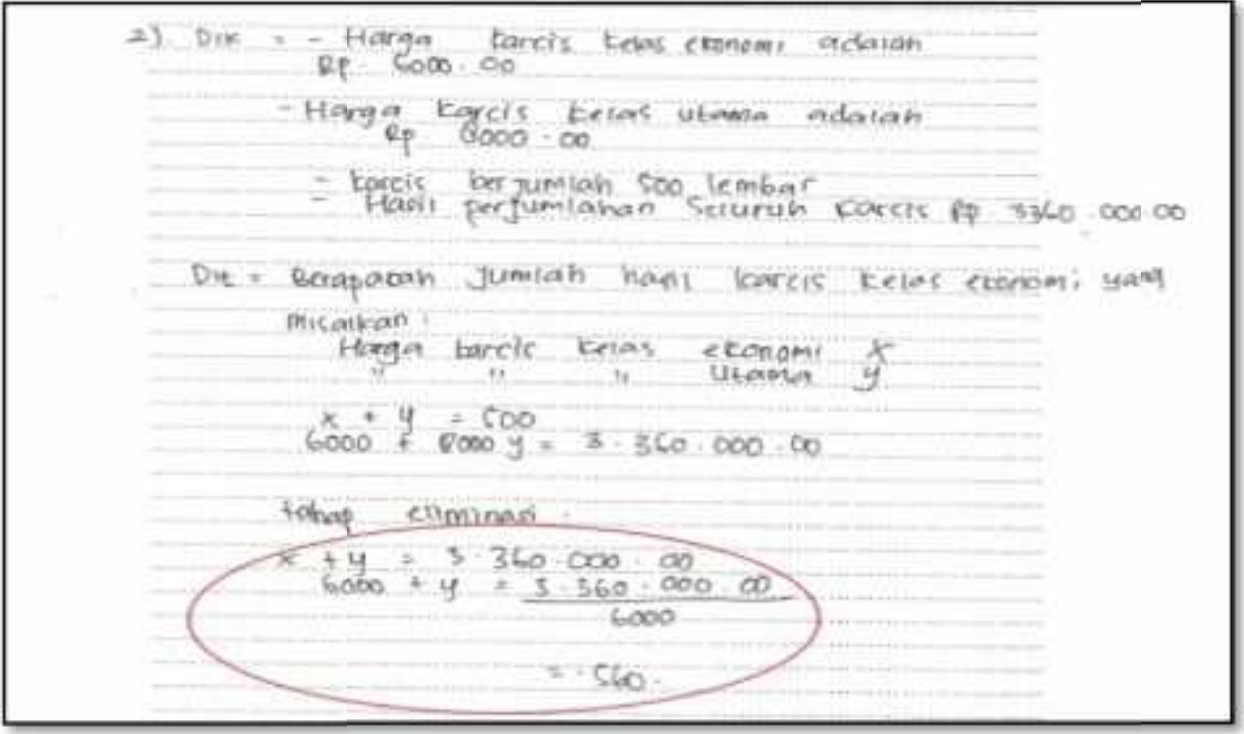

Gambar 5. Jawaban $\mathrm{S}_{3}$ terhadap soal nomor 2

Berdasarkanhasilpadalembarpenyelesaiandanwawancara,

bahwa $\mathrm{S}_{3}$ mengalamikesalahanpadatahapketerampilan proses sertatidakmenuliskanjawabanakhir. dalammenggunakanmetodepenyelesaiannya, danmelakukankesalahanpadatahapketerampilan proses.

Hasilpekerjaan $\mathrm{S}_{3}$ terhadapsoalnomor 3 sepertipadagambar 6 berikut.

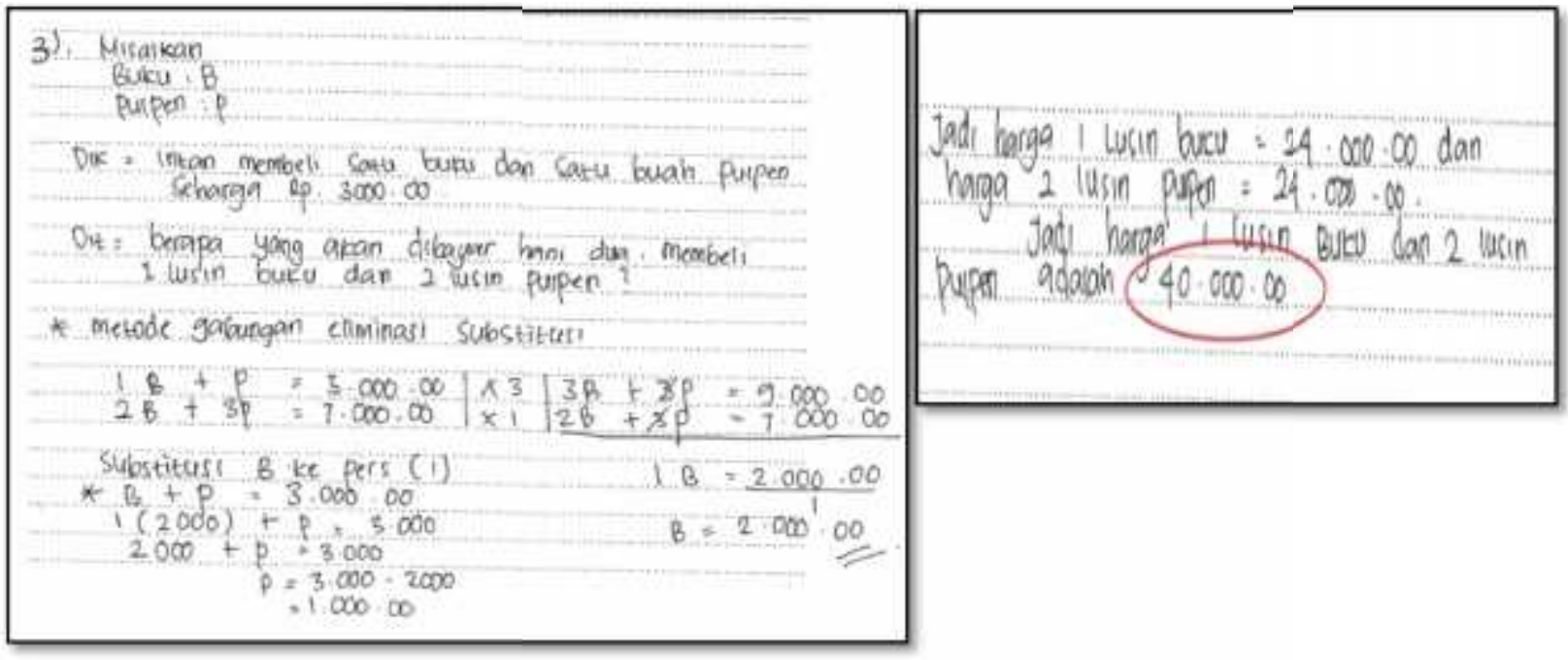

Gambar 6. Jawaban $S_{3}$ terhadap soal nomor 3 


\section{Range: Jurnal Pendidikan Matematika Vol.1 No.2 Tahun 2020 Ayu Habibah, dkk.}

Berdasarkan hasil pada lembar penyelesaian dan wawancara, bahwa $S_{3}$ mengalami kesalahan pada tahap penulisan jawaban akhir, $S_{3}$ melakukan kesalahan dalam menghitung operasi penjumlahan, sehingga jawabannya kurang tepat.

Selanjutnya berkaitan dengan faktor penyebab siswa melakukan kesalahan dalam menyelesaikan soal cerita pada materi Sistem Persamaan Linear Dua Variabel adalah siswa kurang terbiasa mengerjakan soal cerita dengan tahapan-tahapan yang sistematis, misalnya dimulai dangan menuliskan bagian yang diketahui dan yang ditanyakan dalam soal. Kemudian penyebab subjek melakukan kesalahan pada tahap transformasi soal (transformation) yaitu karena kurang memahami dalam merubah makna kata ke model matematika dan salah menuliskannya, sehingga tidak bisa menyusun makna kata yang dipikirkan ke bentuk kalimat matematika atau mentransformasikan kalimat bahasa sehari-hari ke dalam persamaan matematika. Selanjutnya penyebab kesalahan pada tahap keterampilan proses (process skill) karena subjek kurang lengkap dalam menuliskan keterangan rumus, kurang latihan mengerjakan soal bentuk cerita dengan variasi berbeda. Penyebab subjek melakukan kesalahan pada tahap penulisan jawaban akhir (encoding) karena kurang teliti dalam melakukan operasi perhitungan, salah dalam tahap sebelumnya yakni tahap keterampilan proses, yang berakibat penulisan jawaban akhir tidak tepat.

\section{Simpulan}

Berdasarkan hasil penelitian ditemukan bahwa kesalahan yang banyak dilakukan ialah pada tahap keterampilan proses dan penulisan jawaban akhir. Adapun faktor-faktor yang menyebabkan kesalahan siswa dalam menyelesaikan soal cerita tersebut karena tidak terbiasa menyelesaikan soal dengan menggunakan prosedur Newman. Siswa kurang memahami dalam mengubah makna kata ke dalam model matematika. Siswa kurang latihan mengerjakan soal cerita.

\section{DaftarPustaka}

Rindyana, B. S. B.\& Chandra T. D. (2013). Analisis Kesalahan Siswa Dalam Menyelesaikan Soal Cerita Matematika Materi Sistem Persamaan Linear Dua Variabel Berdasarkan Analisis Newman. Jurnal Pendidikan Matematika Universitas Negeri Malang.

Oktaviana, D.(2017). Analisis Tipe Kesalahan Berdasarkan Teori Newman Dalam Menyelesaikan Soal Cerita Pada Mata Kuliah Matematika Diskrit. Jurnal Pendidikan Sains \& Matematika, vol.5 no.2, hal.22-32, 2017

Kholishoh, F. N. N., Pramudya, I.\& Kurniawati, I. (2017). Analisis Kesalahan Dalam Menyelesaikan Soal Cerita Dengan Fong's Schematic Model for Error Analysis Pada Materi Volume Prisma Dan Limas Ditinjau Dari Gender Siswa Kelas VIII E SMP Negeri 1 Kartasura Tahun Ajaran 2015/2016. Jurnal Pendidikan Matematika dan Matematika (JPMM) Solusi, Vol.I No.1, hal.16-35, Januari 2017

Nurussafa'at, F. A., Sujadi, I, \&Riyadi. (2016). Analisis Kesalahan Siswa Dalam Menyelesaikan Soal Cerita Pada Materi Volume Prisma Dengan Fong's Shcematic Model for Error Analysis Ditinjau Dari Gaya Kognitif Siswa (Studi Kasus Siswa Kelas VIII Semester II Smp It Ibnu Abbas Klaten Tahun Ajaran 2013/2014). Jurnal Elektronik Pembelajaran Matematika, vol.4 no.2, hal 174-187, April 2016

Moleong, L. J. (2011). Metode Penelitian Kualitatif. Bandung : Remaja Rosdakarya

Rahmania, L.,\& Rahmawati, A. (2016). Analisis Kesalahan Siswa Dalam Menyelesaikan Soal Cerita Persamaan Linier Satu Variabel (Analysis of Student's Errors In Solving Word Problems Of Linear Equations In One Variable. Jurnal Matematika dan Pendidikan Matematika, vol. 1 no. 2, hal 165173, September 2016

Mulyadi, Riyadi, \&Subanti, S. (2015). Analisis Kesalahan Dalam Menyelesaikan Soal Cerita Pada Materi Luas Permukaan Bangun Ruang Berdasarkan Newman's Error Analysis (NEA) Ditinjau Dari Kemampuan Spasial. Jurnal Elektronik Pembelajaran Matematika, vol.3 no.4, hal 370-382, Juni 2015 


\section{Range: Jurnal Pendidikan Matematika Vol.1 No.2 Tahun 2020 Ayu Habibah, dkk.}

Farida, N. (2015). Analisis Kesalahan Siswa SMP Kelas VIII Dalam Menyelesaikan Masalah Soal Cerita Matematika. Jurnal Pendidikan Matematika FKIP Univ. Muhammadiyah Metro vol. 4 no. 2, hal.42-52

Rahayuningsih, P.,\& Qohar, A. (2014). Analisis Kesalahan Siswa Menyelesaikan Soal Cerita Sistem Persamaan Linear DuaVariabel (SPLDV) Dan Scaffolding-Nya Berdasarkan Analisis kesalahan Newman Pada SiswaKelas VIII Smp Negeri 2 Malang. Jurnal pendidikan Matematika dan SainsTahun II, No. 2, hal.109-116, Desember 2014

Son, A. L., Darhim, \& Fatimah, S. (2019). An Analysis to Student Error of Algebraic Problem Solving Based on Polyaand Newman Theory. Journal of Physics, 2019, (online), (https://iopscience.iop.org/article/10.1088/1742-6596/1315/1/012069). Diakses 7 oktober 2019.

Sugiyono. (2017). Metode Penelitian Kuantitatif, Kualitatifdan R\&D. Bandung: Alfabeta 